Fukushima, D. K., Leeds, N. S., Bradlow, H. L., Kritchevsky, T. H., Stokem, M. B. \& Gallagher, T. F. (1955). J. biol. Chem. 212, 449.

Glenn, E. M., Stafford, R. O., Lyster, S. C. \& Bowman, B. J. (1957). Endocrinology, 61, 128.

Hechter, O. (1955). Vitam. \& Horm. 13, 293.

Herz, J. E., Fried, J. \& Sabo, E. F. (1956). J. Amer. chem. Soc. 78, 2017.

Hodges, J. R. \& Vernikos, J. (1958). Brit. J. Pharmacol. $13,98$.

Liddle, G. W., Richard, J. E. \& Tomkins, G. H. (1956). Metabolism, 5, 384.

Lieberman, S. \& Teich, S. (1953). Pharmacol. Rev. 5, 285.

Martin, A. J. P. (1950). Annu. Rev. Biochem. 19, 517.

Meyer, A. (1955). J. org. Chem. 20, 1240.

Norymberski, J. K. (1952). Nature, Lond., 170, 1074.

Norymberski, J. K. \& Sermin, A. T. (1953). Biochem. J. 55, 876.

Pauling, L. (1940). The Nature of the Chemical Bond, 2nd ed., p. 187. Ithaca, N.Y.: Cornell University Press.
Peterson, R. E., Pierce, C. E., Wyngaarden, J. B., Bunim, J. J. \& Brodie, B. B. (1957). J. clin. Invest. 36, 1301.

Roberts, S. \& Szego, C. (1955). Annu. Rev. Biochem. 24, 543.

Savard, K. (1954). Recent Progr. Hormone Res. 9, 185.

Savard, K., Burstein, S., Rosenkrantz, H. \& Dorfman, R. I. (1953). J. biol. Chem. 202, 717.

Schneider, J. J., Lewbart, M., Levitan, P. \& Lieberman, S. (1955). J. Amer. chem. Soc. 77, 4184.

Shoppee, C. W. (1946). J. chem. Soc., p. 1138.

Talalay, P., Fishman, W. H. \& Huggins, C. (1946). J. biol. Chem. 166, 757.

Talalay, P. \& Williams-Ashman, H. G. (1958). Proc. nat. Acad. Sci., Wash., 44, 15.

Tomkins, G. (1956). Recent Progr. Hormone Res. 12, 125.

Vennesland, B. \& Westheimer, F. H. (1954). In The Mechanism of Enzyme Action, p. 357. Ed. by McElroy, W. D. \& Glass, B. Baltimore: Johns Hopkins Press.

Villee, C. A. (1955). J. biol. Chem. 215, 171.

Wilson, H. (1954). Arch. Biochem. Biophys. 52, 217.

\title{
Studies on the Biosynthesis of Riboflavin
}

\section{GENERAL FACTORS CONTROLLING FLAVINOGENESIS IN THE YEAST CANDIDA FLARERI*}

\author{
By T. W. GOODWIN AND D. McEVOY \\ Department of Biochemistry, The University, Liverpool 3
}

\section{(Received 18 August 1958)}

Among the flavinogenic fungi most studied from the point of view of the biosynthesis of riboflavin are the Ascomycetes Eremothecium ashbyii (Schopfer, 1944; MacLaren, 1952; Goodwin \& Pendlington, 1954; McNutt, 1954, 1956; Brown, Goodwin \& Pendlington, 1955; Goodwin \& Jones, 1956; Brown, Goodwin \& Jones, 1958) and Ashbya gossypii (Tanner, Vojnovich \& van Lanen, 1949; Plaut, 1954a, $b$; Plaut \& Broberg, 1956). Certain yeasts of the genus Candida, e.g. C. guilliermondia (Burkholder, 1943) and C. flareri (Tanner, Vojnovich \& van Lanen, 1945), are also good riboflavin producers, but have not been examined in such detail. The present investigation was undertaken to define more precisely the general factors controlling flavinogenesis in $C$. flareri and to compare the results with those already obtained in this Laboratory with $E$. ashbyii. C. flareri was preferred to $C$. guilliermondia because it synthesizes considerably more riboflavin (Tanner et al. 1945).

The most critical constituent of the medium for flavinogenesis in Candida spp. is undoubtedly iron; the optimum concentration is $0.005-0.01 \mu \mathrm{g} . / \mathrm{ml}$. and higher concentrations are strongly inhibitory (Tanner et al. 1945; Levine, Oyaas, Wasserman, Hoogerheide \& Stern, 1949). This permissible

* Part 4. Brown, Goodwin \& Jones, 1958. concentration of iron can be increased ten times by controlling the amount of cobalt in the medium (10 $\mu \mathrm{g} . / \mathrm{ml}$.) (Enari, 1955). According to Levine et al. (1949), other trace elements (manganese, copper, zinc, tin, nickel and aluminium) up to $0 \cdot 10 \mu \mathrm{g} . / \mathrm{ml}$. have no inhibitory effect on flavinogenesis, whereas zinc at slightly higher concentrations $(0 \cdot 2-0 \cdot 8 \mu \mathrm{g} . / \mathrm{ml}$.) is stimulatory (Schopfer \& Knüsel, 1956).

Because the significance of iron was not known when the original investigations on Candida spp. were carried out (Burkholder, 1943, 1944) the results obtained must be considered quantitatively suspect.

Both $C$. guilliermondia and $C$. flareri will produce riboflavin on a medium containing ammonium sulphate or urea as the sole nitrogen source, but urea is rather more effective in C. flareri (Levine et al. 1949). Supplementation of a medium containing ammonium sulphate as its sole nitrogen source with asparagine, glycine or urea stimulated further flavin production in C. guilliermondia and C. flareri (Burkholder, 1944; Levine et al. 1949).

Aeration or agitation or both is required for good yields of riboflavin, which reach its peak 3-5 days after inoculation (Levine et al. 1949).

Some of the present results have already been briefly reported (Goodwin \& McEvoy, 1957). 


\section{EXPERIMENTAL}

Organism. The organism used throughout was Candida flareri, NRRL 245, kindly provided by the North Regional Research Laboratories, Peoria, Ill., U.S.A. It was maintained by fortnightly transfers on Sabouraud medium-agar slopes.

Media. The basal medium contained (in $100 \mathrm{ml}$.): glucose, 2.0 g.; $\left(\mathrm{NH}_{4}\right)_{2} \mathrm{SO}_{4}, 0.873 \mathrm{~g}$; $\mathrm{KH}_{2} \mathrm{PO}_{4}, 0.05 \mathrm{~g}$.; $\mathrm{MgSO}_{4}, 7 \mathrm{H}_{2} \mathrm{O}, 0.05 \mathrm{~g}$.; $\mathrm{CaCl}_{2}, 0.03 \mathrm{~g}$.; biotin, $0.1 \mu \mathrm{g}$.; B (as $\mathrm{Na}_{2} \mathrm{~B}_{4} \mathrm{O}_{7}, 10 \mathrm{H}_{2} \mathrm{O}$ ), $1 \mu \mathrm{g}$; $\mathrm{Mn}$ (as $\mathrm{MnSO}_{4}, 4 \mathrm{H}_{2} \mathrm{O}$ ), $1 \mu \mathrm{g}$; $\mathrm{Zn}$ (as $\mathrm{ZnSO}_{4}, 7 \mathrm{H}_{2} \mathrm{O}$ ), $7 \mu \mathrm{g}$.; $\mathrm{Cu}$ (as $\mathrm{CuSO}_{4}, 5 \mathrm{H}_{2} \mathrm{O}$ ), $1 \mu \mathrm{g}$.; Mo [as $\left.\left(\mathrm{NH}_{4}\right)_{6} \mathrm{MO}_{7} \mathrm{O}_{24}, 4 \mathrm{H}_{2} \mathrm{O}\right], 1 \mu \mathrm{g}$. $; \mathrm{Fe}$ as $\left[\mathrm{FeSO}_{4},\left(\mathrm{NH}_{4}\right)_{2} \mathrm{SO}_{4}, 6 \mathrm{H}_{2} \mathrm{O}\right]$, $1 \mu \mathrm{g}$. This medium is similar to that of Burkholder (1943, 1944) except that the concentrations of $\left(\mathrm{NH}_{4}\right)_{2} \mathrm{SO}_{4}$ and iron are lower. The trace elements and $\left(\mathrm{NH}_{4}\right)_{2} \mathrm{SO}_{4}$ were stored in concentrated solutions and added in appropriate amounts to the media just before autoclaving. All the chemicals were of analytical grade; the deionized water used was that obtained from an Elgastat and had an electrical conductivity of not less than $800000 \Omega$. To eliminate sources of error from contamination with traces of iron, all glassware was soaked in chromic acid for $24 \mathrm{hr}$., washed with tap water and then with deionized water, and dried in an oven at $150^{\circ}$. The further precaution of autoclaving the glassware completely filled with deionized water at $20 \mathrm{lb}$./in. ${ }^{2}$ for $30 \mathrm{~min}$. before drying (Waring \& Werkman, 1942) was found in preliminary experiments not to be necessary. The pH was adjusted to $5 \cdot 0$ and the medium was sterilized by autoclaving at $15 \mathrm{lb}$./in. ${ }^{2}$ for $15 \mathrm{~min}$. Experimental media made by replacing $\left(\mathrm{NH}_{4}\right)_{2} \mathrm{SO}_{4}$ by amino acids and purines (obtained from L. Light and Co., Colnbrook, Bucks., British Drug Houses Ltd., Poole, Dorset, or Roche Products Ltd., Welwyn Garden City, Herts) in the basal medium were sterilized in the same way.

Cultural conditions. Media (15 ml.) were dispensed in $75 \mathrm{ml}$. Erlenmeyer flasks, inoculated with three drops of a spore suspension drawn from a 2 days' culture grown on the basal medium and the flasks incubated in a rotary shaker in a room maintained at $28 \mp 1^{\circ}$. [We are very grateful to Roche Products Ltd. (Dr A. L. Morrison) for the loan of the prototype of the shaker used in the present investigation.] It had been previously reported that shaking is necessary for good yields of riboflavin (Burkholder, 1944); we confirmed this and noted that static cultures of $C$. flareri produced almost no riboflavin. The use of a 2 days' inoculum was prompted by the fact that it is most suitable with A. gossypii (Tanner et al. 1949) and $E$. ashbyii (Goodwin \& Pendlington, 1954) and that it is recommended in much patent literature (see Goodwin, 1959). It is essential to maintain standardized inoculating conditions, for Burkholder (1944) found that increasing the size of the inoculum decreased riboflavin production.

Removal of iron. When necessary, excess of iron was removed from media by shaking with a solution of 8hydroxyquinoline in chloroform (Waring \& Werkman, 1942; Tanner et al. 1945).

Analytical procedures. In general four replicate flasks were examined in each experiment, and the dry weight of the cells and the riboflavin levels in the media were determined as previously described for $E$. ashbyii (Goodwin \& Pendlington, 1954). In Candida spp. essentially all the riboflavin is present in the culture medium; no significant amount is retained in the mycelium (Burkholder, 1944). In this the organisms differ from $E$. ashbyii and A. gossypii, which can retain considerable amounts in the mycelium (Goodwin, 1959).

The methods of Brown et al. (1958) were used for chromatographic separation and spectrophotometric determination of purines.

\section{RESULTS}

\section{Reproducibility of results}

In an experiment designed to assess the reproducibility of results in replicate flasks, 20 shake cultures grown for 3 days at $28^{\circ}$ on $15 \mathrm{ml}$. of basal medium in $75 \mathrm{ml}$. conical flasks were examined. The results were as follows: dry wt. (mg.), mean 54.6干s.D. $0 \cdot 83$, range $52 \cdot 6-55 \cdot 8$; riboflavin ( $\mu \mathrm{g} . / 15 \mathrm{ml}$.), mean 206 干.D. $11 \cdot 6$, range, $174-224$; riboflavin (mg./ $100 \mathrm{~g}$. of dry mycelium), mean $377 \mp$ s.D. $22 \cdot 9$, range 318-413. Because of these results it was considered necessary generally to carry out subsequent analyses only in quadruplicate.

\section{Effect of the incubation period on growth and flavinogenesis}

In the basal medium under our conditions, growth and flavinogenesis are essentially complete after incubation for 2-3 days (Fig. 1), and after a

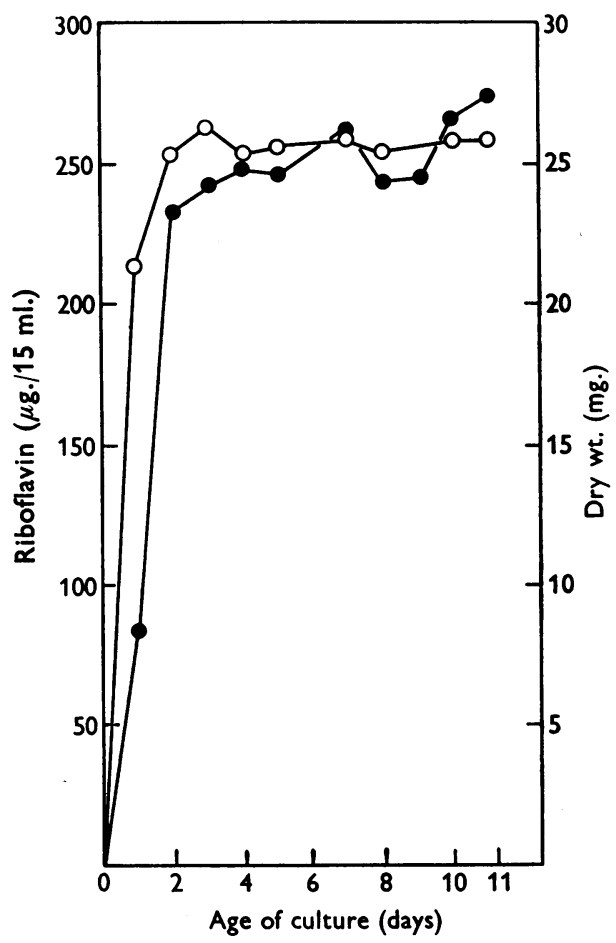

Fig. 1. Effect of age of culture on growth and flavinogenesis in $C$. flareri. Amounts were produced in $15 \mathrm{ml}$. of basal medium in $75 \mathrm{ml}$. flasks; shake culture; temp. $28^{\circ}$. o, Riboflavin; $O$, dry wt. 
further 8 days there is little significant change. Because of these results all later analyses were carried out on 3 days' cultures.

\section{Effect of iron on flavinogenesis}

Addition of iron to the basal medium (Fig. 2) shows little significant effect below $2 \cdot 0 \mu \mathrm{g} . / 100 \mathrm{ml}$., but above this concentration there is a very marked decrease in flavinogenesis. There is no effect on growth of the organism. These results indicate that the iron content of the basal medium was of the right order to support maximum flavinogenesis. Because of this confirmation of previous workers' observations on the effect of higher concentrations of iron on flavinogenesis by Candida spp., in experiments involving additions of extra constituents, the effect of shaking with 8-hydroxyquinoline was generally examined. This procedure was especially important if the substance under test was considered to be a stimulator of flavinogenesis and was found on first investigation not to be so.

Leviton (1946) found that if the iron content were not too high the sensitivity of the flavinogenic

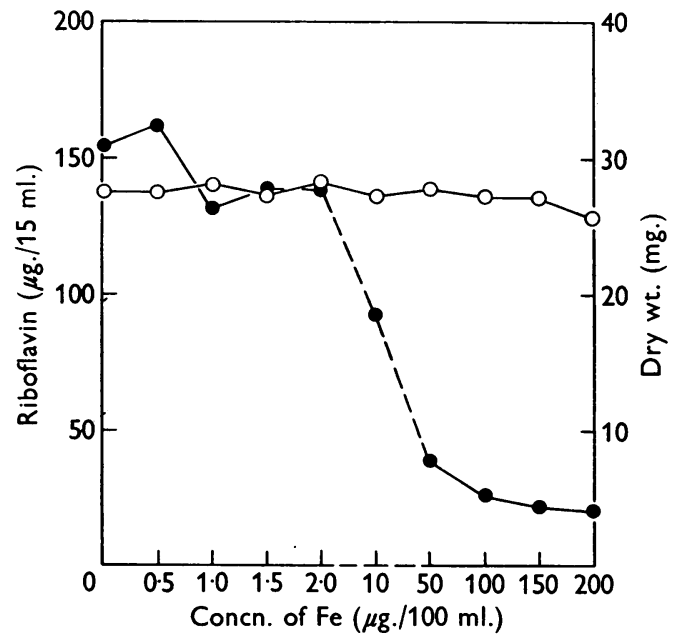

Fig. 2. Effect of iron on growth and flavinogenesis in C. flareri. Basal medium + varying amounts of $\mathrm{Fe}$ as $\mathrm{FeSO}_{4}\left(\mathrm{NH}_{4}\right)_{2} \mathrm{SO}_{4}, 6 \mathrm{H}_{2} \mathrm{O}$; other conditions were as given in Table 1. Riboflavin; $\bigcirc$, dry wt. system in the anaerobic Clostridium acetobutylicum to iron could be overcome by the addition of catalase. The explanation given was that $\mathrm{H}_{2} \mathrm{O}_{2}$ produced metabolically would in the presence of iron rapidly oxidize riboflavin. Addition of catalase destroyed the $\mathrm{H}_{2} \mathrm{O}_{2}$ and thus protected the riboflavin. This approach was examined with Candida flareri; a known amount of iron was added to the basal medium so as to make the final concentration 0.1 p.p.m., and after incubation for $24 \mathrm{hr}$. a solution of catalase (L. Light and Co. Ltd.) was added to one set of flasks. The results (Table 1) show that with this catalase does not overcome the inhibitory effect of excess of iron. Furthermore, if riboflavin is added to a culture of $C$. flareri growing on an iron-rich medium there is no destruction of this added riboflavin. In Clostridium acetobutylicum added riboflavin is destroyed in a medium rich in iron. It is obvious that excess production of $\mathrm{H}_{2} \mathrm{O}_{2}$ resulting from a deficiency of catalase is not the explanation of the sensitivity to iron of the flavinogenic system in $C$. flareri. The same conclusion was recently reached with the closely related $C$. guilliermondia (Shavlovskii \& Chistiakova, 1956).

\section{Effect of other trace elements}

The removal en bloc of the other trace elements (B, Mn, $\mathrm{Zn}, \mathrm{Cu}$ and $\mathrm{Mo}$ ) recommended by Burkholder (1943) reduced markedly riboflavin production, whereas growth was only slightly affected (Table 2). In this experiment L-asparagine was

Table 1. Effect of added catalase on riboflavin pro. duction by Candida flareri on an iron-rich medium

Amounts produced in $75 \mathrm{ml}$. conical flasks containing $15 \mathrm{ml}$. of basal medium plus $0 \cdot 1 \mu \mathrm{g}$. of iron $/ \mathrm{ml}$., with and without the addition of catalase (5 Kiel* units/flask) (added $24 \mathrm{hr}$. after inoculation); 3 days' shake cultures; temp. $28^{\circ}$.

Concn. of $\mathrm{Fe}$
in medium
$(\mu \mathrm{g} . / \mathrm{ml}$.
0.01
0.1

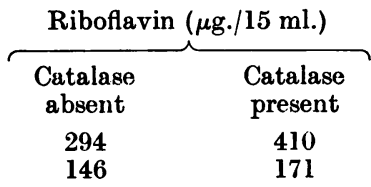

* A Kiel unit is the quantity of catalase necessary to decompose $1 \mathrm{~g}$. of $100 \% \mathrm{H}_{2} \mathrm{O}_{2}$ in $10 \mathrm{~min}$. at $25^{\circ}$ in an inert atmosphere of $\mathrm{CO}_{2}$ or $\mathrm{N}_{2}$.

Table 2. Effect of trace elements on growth and riboflavin synthesis by Candida flareri

Basal medium plus L-asparagine $(0 \cdot 2 \mathrm{~g} . / 100 \mathrm{ml}$.) with and without addition of trace elements $\mathrm{B}, \mathrm{Mo}, \mathrm{Zn}, \mathrm{Cu}$ and $\mathrm{Mn}$. 2,4 and 7 days' shake cultures; temp. $28^{\circ}: 15 \mathrm{ml}$. of medium in $75 \mathrm{ml}$. conical flasks; triplicate determinations.

\begin{tabular}{|c|c|c|c|c|c|c|}
\hline & \multicolumn{2}{|c|}{2 days' cultures } & \multicolumn{2}{|c|}{4 days' cultures } & \multicolumn{2}{|c|}{7 days' cultures } \\
\hline & $\begin{array}{c}\text { Dry wt. } \\
\text { (mg.) }\end{array}$ & $\begin{array}{l}\text { Riboflavin } \\
(\mu \mathrm{g} . / 15 \mathrm{ml} .)\end{array}$ & $\begin{array}{l}\text { Dry wt. } \\
\text { (mg.) }\end{array}$ & $\begin{array}{c}\text { Riboflavin } \\
(\mu \mathrm{g} . / 15 \mathrm{ml} .)\end{array}$ & $\begin{array}{c}\text { Dry wt. } \\
\text { (mg.) }\end{array}$ & $\begin{array}{c}\text { Riboflavin } \\
(\mu \mathrm{g} . / 15 \mathrm{ml} .)\end{array}$ \\
\hline $\begin{array}{l}\text { Basal medium with trace } \\
\text { elements }\end{array}$ & $61 \cdot 1$ & 520 & 53.9 & 610 & $52 \cdot 3$ & 502 \\
\hline $\begin{array}{l}\text { Basal medium without } \\
\text { trace elements }\end{array}$ & $49 \cdot 9$ & 393 & $49 \cdot 9$ & 313 & $42 \cdot 4$ & 212 \\
\hline
\end{tabular}


added to our basal medium in order to reproduce Burkholder's conditions exactly. In fact Lasparagine is not necessary for flavinogenesis (see Table 6). This problem was not pursued further, but the result indicated that at least one other trace element is concerned in flavinogenesis; in this connexion Schopfer \& Knüsel (1956) indicated that zinc was important.

\section{Effect of glucose and phosphate}

These two compounds are grouped together because their reported effect on flavinogenesis is similar. According to Burkholder (1943) increasing the concentration of phosphate or of glucose in the medium inhibited flavinogenesis; we have confirmed both these observations and have further shown that the effects are due to the extra iron added to the medium in increasing the concentrations of phosphate and glucose. If the solutions of

Table 3. Effect of removal of iron on the inhibitory action on flavinogenesis by Candida flareri of high concentrations of glucose and phosphate

Medium $A$ : basal medium with glucose concn. increased to $4.0 \%(\mathrm{w} / \mathrm{v})$. Medium $B$ : basal medium with $\mathrm{KH}_{2} \mathrm{PO}_{4}$ concn. increased to $0.0875 \%(20 \mathrm{mg}$. of $\mathrm{P} / 100 \mathrm{ml}$.). Iron was removed by shaking with 8-hydroxyquinoline. Other conditions were as described in Table 1 except that nine flasks were examined in each group.
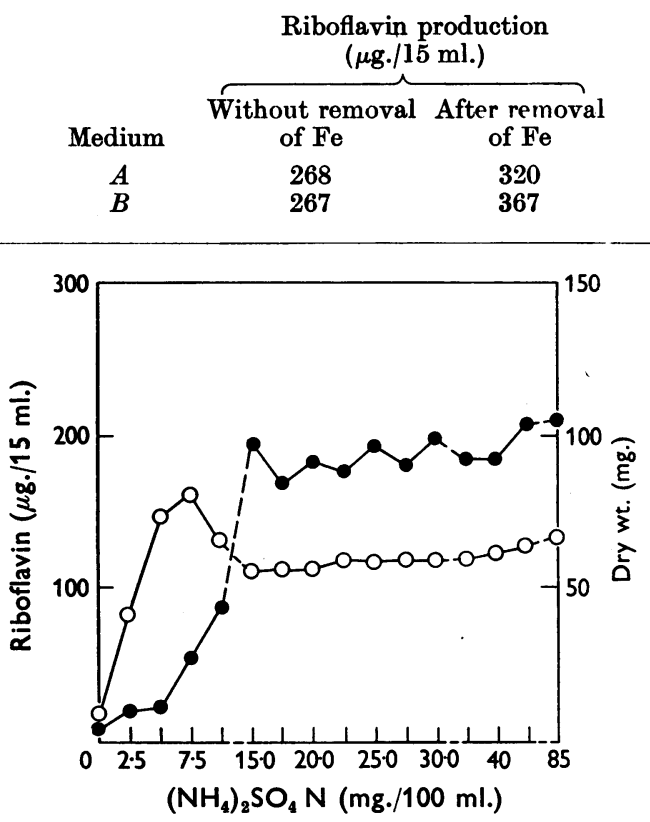

Fig. 3. Effect of $\left(\mathrm{NH}_{4}\right)_{2} \mathrm{SO}_{4}$ concentration on growth and flavinogenesis in E. ashbyii. Amounts in $15 \mathrm{ml}$. of basal medium with varying concentrations of $\left(\mathrm{NH}_{4}\right)_{2} \mathrm{SO}_{4}$; shake cultures; temp. $28^{\circ}$. Quadruplicate determinations. Riboflavin; $O$, dry wt. these constituents are shaken with 8-hydroxyquinoline before being added to the basal medium, then the inhibitory effect vanishes (Table 3). It is obvious that, with our glucose, the concentration recommended by Burkholder (1944) and used throughout the present work produces slightly less than maximal amounts of riboflavin, and that the concentration ( $4 \%$ ) recommended by Tanner et al. (1945) is too high.

\section{Effect of varying the concentration of ammonium sulphate}

Growth of $C$. flareri reaches its maximum with $7.5 \mathrm{mg}$. of $\left(\mathrm{NH}_{4}\right)_{2} \mathrm{SO}_{4}$ nitrogen $/ 100 \mathrm{ml}$.; increasing the amount above $7.5 \mathrm{mg}$. of nitrogen/100 ml. results in decreased growth until it levels off at $15 \mathrm{mg}$. of nitrogen/100 ml. and above (Fig. 3). This type of growth curve is completely reproducible. Riboflavin production, on the other hand, increases rapidly to a maximum at $15 \mathrm{mg}$. of $\left(\mathrm{NH}_{4}\right)_{2} \mathrm{SO}_{4}$ nitrogen/100 ml. It may be significant that the greatest increase in flavinogenesis occurs over that range where a decrease in growth is noted.

It was found that $\mathrm{NH}_{4} \mathrm{NO}_{3}$ and ammonium acetate would satisfactorily replace $\left(\mathrm{NH}_{4}\right)_{2} \mathrm{SO}_{4}$ but that $\mathrm{KNO}_{3}$ would not support growth of $C$. flareri.

\section{Effect of certain amino acids}

When $\left(\mathrm{NH}_{4}\right)_{2} \mathrm{SO}_{4}$ in the basal medium was replaced by various amino acids it was found that they could be divided into two groups: $(a)$ those which stimulated growth very considerably and (b) those which supported equal or less growth (Table 4). Urea, which was also examined, was in the first group. The experiments were carried out at different times, and the growth of the $\left(\mathrm{NH}_{4}\right)_{2} \mathrm{SO}_{4}$ controls varied slightly from experiment to experiment; in order to collect the results into one table, growth is expressed as the percentage of that of the appropriate $\left(\mathrm{NH}_{4}\right)_{2} \mathrm{SO}_{4}$ control. In none of these experiments did the riboflavin levels reach those achieved on $\left(\mathrm{NH}_{4}\right)_{2} \mathrm{SO}_{4}$ alone. This could have been due either to the presence of iron in the amino acids added or to the fact that as growth was so much better in many cases than on $\left(\mathrm{NH}_{4}\right)_{2} \mathrm{SO}_{4}$, no residual nitrogen was available for channelling into riboflavin. All the strongly growth-stimulating amino acids and urea were therefore examined at higher concentrations, and Table 5 shows that under these circumstances $(40 \mathrm{mg}$. of nitrogen/ $100 \mathrm{ml}$.) L-arginine and urea produce much more riboflavin than does $\left(\mathrm{NH}_{4}\right)_{2} \mathrm{SO}_{4}$, but as growth is also considerably increased the yield per unit dry weight of cells is of the same order in all three cases. Glycine, L-asparagine and $\left(\mathrm{NH}_{4}\right)_{2} \mathrm{SO}_{4}$ are equally flavinogenic, but as growth is much greater with the amino acids the yield per unit dry weight of 
cells is very much less than on $\left(\mathrm{NH}_{4}\right)_{2} \mathrm{SO}_{4}$. None of the other amino acids examined, DL-serine, Laspartic acid, DL-glutamic acid and DL-threonine, which stimulate flavinogenesis in $E$. ashbyii (Goodwin \& Pendlington, 1954), and DL-ornithine and DL-citrulline, studied because of the activity of urea and L-arginine, supported flavinogenesis comparably with that achieved on $\left(\mathrm{NH}_{4}\right)_{2} \mathrm{SO}_{4}$. The possibility of the presence of iron in these amino

Table 4. Effect of different amino acids on the growth of Candida flareri

Basal medium with $\left(\mathrm{NH}_{4}\right)_{2} \mathrm{SO}_{4}$ replaced by either 7.5 or $20.0 \mathrm{mg}$. of amino acid $\mathrm{N} / 100 \mathrm{ml}$. DL-Amino acids were added at twice the normal concentration. Other conditions were as described in Table 1.

\begin{tabular}{|c|c|c|}
\hline \multirow[b]{2}{*}{ Nitrogen source } & \multicolumn{2}{|c|}{$\begin{array}{l}\text { Growth } \\
{\left[\% \text { of that on }\left(\mathrm{NH}_{4}\right)_{2} \mathrm{SO}_{4}\right]}\end{array}$} \\
\hline & $\begin{array}{l}7.5 \mathrm{mg} . \text { of } \\
\mathrm{N} / 100 \mathrm{ml} .\end{array}$ & $\begin{array}{l}20 \mathrm{mg} . \text { of } \\
\mathrm{N} / 100 \mathrm{ml} .\end{array}$ \\
\hline$\left(\mathrm{NH}_{4}\right)_{8} \mathrm{SO}_{4}$ & 100 & 100 \\
\hline DL-Serine & 194 & 456 \\
\hline Glycine & 179 & 489 \\
\hline L-Aspartic acid & 199 & 568 \\
\hline L-Asparagine & 164 & 488 \\
\hline L-Arginine & 152 & 314 \\
\hline DL-Glutamate & 209 & 535 \\
\hline L-Proline & 179 & 500 \\
\hline DL-Citrulline & 152 & 430 \\
\hline Urea & 154 & $\mathbf{3 4 0}$ \\
\hline DL-Tryptophan & 169 & 156 \\
\hline L-Alanine & 195 & 119 \\
\hline DL-Ornithine & 119 & 256 \\
\hline L-Valine & 114 & 124 \\
\hline L-Tyrosine & $\mathbf{3 3}$ & 150 \\
\hline DL-Threonine & 29 & 49 \\
\hline L-Histidine & 38 & 64 \\
\hline DL-Methionine & 42 & 79 \\
\hline L-Lysine & 86 & 86 \\
\hline L-Leucine & 65 & 87 \\
\hline L-Cysteine & 16 & 72 \\
\hline L-Phenylalanine & 37 & 59 \\
\hline L-Hydroxyproline & $7 \cdot 3$ & 11 \\
\hline
\end{tabular}

acids had to be considered. After shaking the individual amino acid solutions with 8-hydroxyquinoline before their incorporation into the medium, it was found that flavinogenesis was considerably improved with serine and ornithine, very slightly stimulated with $\mathrm{L}$-asparagine, unaltered with DL-threonine and DL-glutamate and, unexpectedly, reduced with DL-citrulline (Table 6).

\section{Effect of purines and pyrimidines}

As sole sources of nitrogen, xanthine and uric acid support good growth but no flavinogenesis, whereas adenine, adenosine and hypoxanthine support no significant growth (Table 7). When added at a level of $12.5 \mathrm{mg}$. of nitrogen/100 ml. to media also containing $7.5 \mathrm{mg}$. of $\left(\mathrm{NH}_{4}\right)_{2} \mathrm{SO}_{4}$ nitrogen/100 ml., then all purines stimulate growth considerably compared with a medium containing $20 \mathrm{mg}$. of $\left(\mathrm{NH}_{4}\right)_{2} \mathrm{SO}_{4}$ nitrogen/100 ml. Xanthine also stimulated flavinogenesis and uric acid was equal to $\left(\mathrm{NH}_{4}\right)_{2} \mathrm{SO}_{4}$. Adenine and hypoxanthine, on the other hand, showed no effect whatever on flavinogenesis. At its maximum level of solubility (5 mg./100 ml.), and in the absence of $\left(\mathrm{NH}_{4}\right)_{2} \mathrm{SO}_{4}$, guanine supported growth but did not stimulate flavinogenesis (Table 8). In the presence of $\left(\mathrm{NH}_{4}\right)_{2} \mathrm{SO}_{4}$ it stimulated both growth and flavinogenesis. The failure of adenine and hypoxanthine to stimulate flavinogenesis might have been due to contamination with iron; however, after shaking with 8-hydroxyquinoline before incorporation into the culture media it was found that the effect of hypoxanthine was unchanged. For a reason which at the moment remains inexplicable growth did not occur on the adenine medium shaken with 8hydroxyquinoline.

By the methods of Brown et al. (1958) it was shown with adenine that in the presence of $\left(\mathrm{NH}_{4}\right)_{2} \mathrm{SO}_{4}$ and under the experimental conditions

Table 5. Effect of high concentrations of certain amino acids on growth and flavinogenesis in Candida flareri

Basal medium with $\left(\mathrm{NH}_{4}\right)_{9} \mathrm{SO}_{4}$ replaced by urea or an amino acid at $\mathrm{N}$ concentrations of either $20 \mathrm{or} 40 \mathrm{mg} . / 100 \mathrm{ml}$. Other conditions were as described in Table 1.

\begin{tabular}{|c|c|c|c|c|}
\hline \multirow[b]{2}{*}{ Nitrogen source } & \multicolumn{2}{|c|}{$\left[\%\right.$ of that on $\left.\left(\mathrm{NH}_{4}\right)_{2} \mathrm{SO}_{4}\right]$} & \multicolumn{2}{|c|}{$\left[\%\right.$ of that on $\left.\left(\mathrm{NH}_{4}\right)_{2} \mathrm{SO}_{4}\right]$} \\
\hline & $\begin{array}{l}20 \mathrm{mg} . \text { of } \\
\mathrm{N} / 100 \mathrm{ml} .\end{array}$ & $\begin{array}{l}40 \mathrm{mg} . \text { of } \\
\mathrm{N} / 100 \mathrm{ml} .\end{array}$ & $\begin{array}{l}20 \mathrm{mg} . \text { of } \\
\mathrm{N} / 100 \mathrm{ml} .\end{array}$ & $\begin{array}{l}40 \mathrm{mg} . \text { of } \\
\mathrm{N} / 100 \mathrm{ml} .\end{array}$ \\
\hline$\left(\mathrm{NH}_{4}\right)_{2} \mathrm{SO}_{4}$ & 100 & 100 & 100 & 100 \\
\hline Glycine & 520 & 576 & 18 & 125 \\
\hline DL-Serine & 371 & 471 & 13 & 65 \\
\hline L-Asparagine & 418 & 458 & 47 & 93 \\
\hline L-Aspartic acid & 507 & 541 & 10 & 18 \\
\hline DL-Glutamate & 513 & 549 & 17 & 23 \\
\hline DL-Ornithine & 275 & 362 & 23 & 19 \\
\hline DL-Citrulline & 359 & 435 & 14 & 18 \\
\hline L-Arginine & 268 & 266 & 71 & 297 \\
\hline Urea & 405 & 415 & 90 & 326 \\
\hline DL-Threonine & 98 & 106 & 8 & 10 \\
\hline
\end{tabular}


described in Table 8 , about $40 \%$ of the added adenine is utilized and that no detectable amounts of extracellular hypoxanthine are produced; this differs from the observation with $E$. ashbyii, where considerable amounts of adenine are converted into hypoxanthine (Brown et al. 1958).

The pyrimidines thymine, uracil, cytosine and orotic acid, when used as sole sources of nitrogen did not support growth of $C$. flareri, and when incorporated into media containing $\left(\mathrm{NH}_{4}\right)_{2} \mathrm{SO}_{4}$ had no effect on either growth or flavinogenesis. These completely negative results are not recorded here.

Table 6. Effect of removal of iron on the flavinogenic action in Candida flareri of high concentrations of certain amino acids

Basal medium with different amino acids or $\left(\mathrm{NH}_{4}\right)_{8} \mathrm{SO}_{4}$ added at concentrations of $40 \mathrm{mg}$. of $\mathrm{N} / 100 \mathrm{ml}$.; iron was removed from amino acid and $\left(\mathrm{NH}_{4}\right)_{2} \mathrm{SO}_{4}$ solutions before addition to basal medium by shaking with 8-hydroxyquinoline. Other conditions were as described in Table 1.

\begin{tabular}{lcc} 
& $\begin{array}{c}\text { Riboflavin [\% of that } \\
\left.\text { produced on }\left(\mathrm{NH}_{4}\right)_{8} \mathrm{SO}_{4}\right]\end{array}$ \\
\cline { 2 - 3 } Nitrogen source & $\begin{array}{c}\text { Before removal } \\
\text { of iron }\end{array}$ & $\begin{array}{c}\text { After removal } \\
\text { of iron }\end{array}$ \\
$\left(\mathrm{NH}_{4}\right)_{8} \mathrm{SO}_{4}$ & 100 & 100 \\
DL-Serine & 79 & 250 \\
L-Asparagine & 22 & 36 \\
DL-Glutamic acid & 21 & 23 \\
DL-Ornithine & 92 & 236 \\
DL-Threonine & 12 & 8 \\
DL-Citrulline & 66 & 7
\end{tabular}

\section{DISCUSSION}

Two types of experiments with $E$. ashbyii and $A$. gossypii point to purines or purine-like compounds as the precursors of rings $B$ and $C$ of riboflavin (see Goodwin, 1959). With isotopically labelled compounds it has been shown that the labelling pattern of rings $B$ and $C$ is the same as that in the purines (Plaut, 1954a, b), and in feeding experiments all purines stimulate flavinogenesis to varying extents. Serine and threonine are also stimulatory, the former by providing both formate and 'glycine' (Goodwin \& Jones, 1956), and the latter by providing 'glycine' (T. W. Goodwin \& A. A. Horton, unpublished observations). As glycine is non-stimulatory it would appear that E. ashbyii cannot activate glycine but that 'active glycine' can arise from the metabolism of serine and threonine.

It is obvious from the present results (Tables 7 and 8) that in $C$. flareri rings $\mathrm{B}$ and $\mathrm{C}$ can also arise from purines for xanthine, the purine most closely related to riboflavin, and to a lesser extent guanine and uric acid are flavinogenic. The relative inactivity of hypoxanthine in $C$. flareri parallels the results with $E$. ashbyii (Brown et al. 1958) and is presumably due to the absence of a xanthine oxidase which could convert it into xanthine. The inactivity of adenine in $C$. flareri contrasts sharply with its effectiveness in $E$. ashbyii (Brown et al. 1958). Although it can be assimilated into the cells of $C$. flareri (Table 7) it cannot be converted into a

Table 7. Effect of various purines on growth and flavinogenesis in Candida flareri

Basal medium with either $7.5 \mathrm{mg}$. of $\left(\mathrm{NH}_{4}\right)_{2} \mathrm{SO}_{4} \mathrm{~N}$ plus $12.5 \mathrm{mg}$. of purine $\mathrm{N} / 100 \mathrm{ml}$. or $20 \mathrm{mg}$. of purine $\mathrm{N} / 100 \mathrm{ml}$. only. Other conditions were as described in Table 1.

\begin{tabular}{|c|c|c|c|c|c|}
\hline \multirow[b]{2}{*}{ Purine added } & \multicolumn{2}{|c|}{ Purine alone } & & \multicolumn{2}{|c|}{ Purine plus $\left(\mathrm{NH}_{4}\right)_{2} \mathrm{SO}_{4}$} \\
\hline & $\begin{array}{c}\text { Dry wt. } \\
\text { (mg.) }\end{array}$ & $\begin{array}{c}\text { Riboflavin } \\
(\mu \mathrm{g} .)\end{array}$ & & $\begin{array}{c}\text { Dry wt. } \\
\text { (mg.) }\end{array}$ & $\begin{array}{c}\text { Riboflavin } \\
(\mu \mathrm{g} .)\end{array}$ \\
\hline $\begin{array}{l}\text { Adenine } \\
\text { Hypoxanthine } \\
\text { Xanthine } \\
\text { Uric acid }\end{array}$ & $\begin{array}{l}\text { No sign } \\
\text { No sign } \\
116 \cdot 4 \\
69 \cdot 4^{*}\end{array}$ & $\begin{array}{l}\text { nt growth } \\
\text { nt growth } \\
59 \\
\text { Trace }\end{array}$ & & $\begin{array}{l}58 \cdot 5 \\
43 \cdot 9 \\
66 \cdot 9 \\
89\end{array}$ & $\begin{array}{r}72 \\
83 \\
562 \\
287\end{array}$ \\
\hline $\begin{array}{l}\text { Control A: } \\
\left.7.5 \text { mg. of }\left(\mathrm{NH}_{4}\right)_{2} \mathrm{SO}_{4} \mathrm{~N} ;\right\} \\
\text { no purine }\end{array}$ & $37 \cdot 9$ & 77 & $\begin{array}{l}\text { Control B: } \\
20 \mathrm{mg} . \text { of }\left(\mathrm{NH}_{4}\right)_{2} \mathrm{SO}_{4} \mathrm{~N} \text {; } \\
\text { no purine }\end{array}$ & $27 \cdot 0$ & 256 \\
\hline
\end{tabular}

Table 8. Effect of guanine on growth and flavinogenesis in Candida flareri

Basal medium with $2 \cdot 32 \mathrm{mg}$. of $\mathrm{N} / 100 \mathrm{ml}$. as $\left(\mathrm{NH}_{4}\right)_{2} \mathrm{SO}_{4}$ alone or as purine alone: or with $9 \cdot 82 \mathrm{mg}$. of $\mathrm{N} / 100 \mathrm{ml}$., as $\left(\mathrm{NH}_{4}\right)_{2} \mathrm{SO}_{4}$ alone or including $2.32 \mathrm{mg}$. of $\mathrm{N} / 100 \mathrm{ml}$. as purine. Other conditions were as described in Table 1.

\begin{tabular}{|c|c|c|c|}
\hline \multicolumn{2}{|c|}{$\mathrm{N}$ content of medium } & $\begin{array}{l}\text { Dry wt. } \\
\text { (mg.) }\end{array}$ & $\begin{array}{c}\text { Riboflavin } \\
(\mu \mathrm{g} .)\end{array}$ \\
\hline $2.32 \mathrm{mg} . / 100 \mathrm{ml}$ & $\left\{\begin{array}{l}(a) \text { as }\left(\mathrm{NH}_{4}\right)_{2} \mathrm{SO}_{4} \\
(b) \text { as guanine }\end{array}\right.$ & $\begin{array}{l}20 \cdot 3 \\
24 \cdot 7\end{array}$ & $\begin{array}{l}19 \\
9 \cdot 5\end{array}$ \\
\hline $9.82 \mathrm{mg} / 100 \mathrm{ml}$ & $\left\{\begin{array}{l}(a) \text { as }\left(\mathrm{NH}_{4}\right)_{2} \mathrm{SO}_{4} \\
(b) \text { as guanine }(2 \cdot 32 \mathrm{mg} . \text { of } \mathrm{N})+ \\
\quad\left(\mathrm{NH}_{4}\right)_{2} \mathrm{SO}_{4}(7.5 \mathrm{mg} \text {. of } \mathrm{N})\end{array}\right.$ & $\begin{array}{l}32 \cdot 9 \\
21 \cdot 7\end{array}$ & $\begin{array}{r}89 \\
218\end{array}$ \\
\hline
\end{tabular}


riboflavin precursor. A possible explanation is that the immediate precursor of riboflavin which is produced in the same way as in $E$. ashbyii cannot be deaminated, for no indication of an adenase converting adenine into hypoxanthine could be obtained. On the other hand, an active adenase is present in $E$. ashbyii.

The stimulatory effect of serine in $E$. ashbyii is reproduced in $C$. flareri, but it is somewhat masked because in the latter serine also stimulates growth. In contrast $(a)$ glycine is stimulatory in $C$. flareri but not in $E$. ashbyii, which suggests that the former can activate glycine, and (b) threonine is stimulatory in $E$. ashbyii but not in $C$. flareri, which suggests that the latter does not possess an enzyme, possibly threonine aldolase, which can cleave threonine to glycine.

There are, however, a group of nitrogenous compounds, urea, arginine and ornithine, which are strongly flavinogenic in $C$. flareri but are quite inactive in $E$. ashbyii. This suggests that in $C$. flareri there is a route of riboflavin synthesis quite distinct from the usual purine pathway. It may involve synthesis of a purine precursor via an unconventional pathway or the direct synthesis of a pyrimidine-like precursor. If the latter is correct the compound formed cannot be any of the conventional pyrimidines, for these are non-stimulatory; however, it is more likely to be a purine because it has already been found that $\left[{ }^{14} \mathrm{C}\right]$ urea is rapidly incorporated into guanine in the algae Chlorella pyrenoidosa and Scenedesmus basilensis (Ellner \& Steers, 1955). This group of compounds, together with citrulline, are the components of the urea cycle in mammals but it is difficult to devise an explanation based on this metabolic cycle because of the inactivity of citrulline; furthermore a thorough search has failed to demonstrate arginase activity in $C$. flareri. The mechanism of incorporation of these compounds into riboflavin is currently being investigated with isotopes.

\section{SUMMARY}

1. On a fully defined medium containing ammonium sulphate as the sole nitrogen source, growth and flavinogenesis in Candida flareri are maximal 2-3 days after inoculation. Growth is maximal with $7.5 \mathrm{mg}$. of ammonium sulphate nitrogen/ $100 \mathrm{ml}$. and flavinogenesis maximal at $15 \mathrm{mg}$. of nitrogen $/ 100 \mathrm{ml}$.

2. The extreme sensitivity of the flavinogenic system to traces of iron was confirmed; the inhibitory effects of high concentrations of glucose and phosphate were due to the iron present in these compounds.
3. Many amino acids greatly stimulate growth but reduce flavinogenesis; glycine, serine, ornithine, arginine and urea stimulate growth and flavinogenesis.

4. Xanthine, guanine and uric acid as sole nitrogen sources support growth of $C$. flareri; adenine and hypoxanthine do not. In the presence of ammonium sulphate all four stimulate growth, but only xanthine, and to a lesser extent guanine and uric acid, stimulate flavinogenesis.

5. The pyrimidines tested, uracil, thymine, cytosine and orotic acid, neither support growth alone nor stimulate growth or flavinogenesis in the presence of ammonium sulphate.

We are grateful to the Agricultural Research Council for a research grant and to the University of Liverpool for a Fellowship (to D.M.).

\section{REFERENCES}

Brown, E. G., Goodwin, T. W. \& Jones, O. T. G. (1958). Biochem. J. 68, 40.

Brown, E. G., Goodwin, T. W. \& Pendlington, S. (1955). Biochem. J. 61, 39.

Burkholder, P. (1943). Proc. nat. Acad. Sci., Wash., 29, 166.

Burkholder, P. (1944). Arch. Biochem. 4, 217.

Ellner, P. D. \& Steers, E. (1955). Arch. Biochem. Biophys. $59,534$.

Enari, T. M. (1955). Acta chem. scand. 9, 1726.

Goodwin, T. W. (1959). Progr. industr. Microbiol. 1, 139.

Goodwin, T. W. \& Jones, O. T. G. (1956). Biochem. J. 64, 9.

Goodwin, T. W. \& McEvoy, D. (1957). Biochem. J. 67, $17 \mathrm{P}$.

Goodwin, T. W. \& Pendlington, S. (1954). Biochem. J. 57, 631.

Levine, H., Oyaas, J. E., Wasserman, L., Hoogerheide, J. C. \& Stern, R. M. (1949). Industr. Engng Chem. 41, 1665.

Leviton, A. (1946). J. Amer. chem. Soc. 68, 835.

MacLaren, J. A. (1952). J. Bact. 63, 233.

McNutt, W. S. (1954). J. biol. Chem. 210, 511.

McNutt, W. S. (1956). J. biol. Chem. 219, 365.

Plaut, G. W. E. $(1954 a)$. J. biol. Chem. 208, 513.

Plaut, G. W. E. (1954b). J. biol. Chem. 211, 11 .

Plaut, G. W. E. \& Broberg, P. L. (1956). J. biol. Chem. 291, 131.

Schopfer, W. H. (1944). Rev. Int. Vitaminol. 20, 116.

Schopfer, W. H. \& Knüsel, F. (1956). Schweiz. Z. path. 19, 659.

Shavlovskii, G. M. \& Chistiakova, V.S. (1956). Dokl. Akad. Nauk, S.S.S.R., 111, 887.

Tanner, F. W., Vojnovich, C. \& van Lanen, J. M. (1945). Science, 101, 180.

Tanner, F. W., Vojnovich, C. \& van Lanen, J. M. (1949). J. Bact. 58, 737.

Waring, W. S. \& Werkman, C. H. (1942). Arch. Biochem. 1, 303. 